\title{
Early boats in Scandinavia: new evidence from Early Iron Age bog finds in Arctic Norway
}

\author{
Stephen Wickler \\ The Arctic University Museum of Norway, Tromsø, Norway. Tel. +47 77645081 Email: \\ stephen.wickler@uit.no ORCID 0000-0002-0467-1966
}

\begin{abstract}
This article considers early boats in Scandinavian spanning a timeframe from Early Mesolithic colonization at c. 9500 cal BC up until the beginning of the Late Iron Age around AD 600 from a northern Norwegian perspective. The role of boats in current models of maritime colonization and proxy evidence from carved rock art images of Bronze Age to Early Iron Age boats are evaluated before focusing on newly dated boat remains from bogs in Arctic Norway currently housed at The Arctic University Museum of Norway. These include paddles predating the Iron Age and finds supporting the existence of rowed plank-built vessels in the early Pre-Roman Iron Age (500-0 BC). Rowing evidence includes a boat frame and oar radiocarbon dated to the 6th to 5th century BC and two oars from the later Pre-Roman Iron Age. Consequently, a revision of thinking about early Iron Age boat development is necessary, not only in Arctic Norway but also elsewhere in Scandinavia and Fennoscandia. The context of the earliest plankbuilt vessel in Scandinavia, the paddled war canoe from Hjortspring, Denmark dated to c. 350 BC, is reevaluated in light of a probable coexistence with rowed boats.
\end{abstract}

Keywords: Scandinavia, Arctic Norway, bog boat finds, Early Iron Age, rowing

\section{Acknowledgements}

First, I wish to thank traditional boat builder Gunnar Eldjarn for his invaluable contribution to the bog boat project through shared nautical expertise and knowledge. His insights into how boats work coupled with experimental attempts to understand oars from the Pre-Roman Iron Age were a key contribution. Comments from Arne Emil Christensen on tentative interpretations of early boat remains were also greatly appreciated. The Arctic University Museum of Norway provided generous funding for dates and dendrochronologist Andreas Kirchhefer played a key role in selecting dating samples. 
Boats have had a pivotal role in maritime settlement and interaction within Scandinavia since postglacial human colonization. However, the lack of physical evidence has been a considerable handicap for nautical archaeology when confronted with the recurring question "where are the boats?" New dates and analytical results from Early Iron Age bog boat remains in Arctic Norway presented here reveal the maritime importance of an assumedly marginal region during this period when viewed from a South Scandinavian perspective. Newly documented Pre-Iron Age boat-related remains that are unique in Norway also provide an opportunity to evaluate the role of watercraft in the North extending back to the Late Stone Age.

\section{Maritime colonization and models of Early Mesolithic settlement: binary thinking and 'primitive' boats}

Although the deglaciation of coastal Scandinavian seascapes occurred at c. 13,500 cal BC, evidence of human settlement does not appear until c. 9500 cal BC (Bjerck 2009; Van de Noort 2011; Rowley-Conwy and Piper 2016). An oft-cited contributing factor for this perceived gap is a lack of seaworthy boats hindering advancement along the coast (Bjerck 2016). Natural barriers such as a glacier around Oslo Fjord may also have delayed coastal colonization (Glørstad 2014). There appears to be an underlying, often implicit, assumption in models of postglacial settlement that Late Pleistocene watercraft were quite primitive and a substantial amount of time was required for the gradual progression to a sufficient state of seaworthiness to permit venturing into marine environments (Glørstad 2013). This negative assessment of early watercraft among scholars has hindered the formulation of alternative maritime colonization models.

There is a broad consensus that pioneer settlement by maritime hunter-forager-gatherers took place in the Early Mesolithic with a rapid dispersal along the entire Norwegian coastline over a period of 200-300 years prior to $9000 \mathrm{cal} \mathrm{BC}$ (Bjerck 2009). It is estimated that more than $90 \%$ of the sites during this period occur on the outer coast, frequently on small islands, and commonly close to natural harbors. The location of a majority of coastal sites on what were islands facing the open ocean at the time demonstrates the essential role of seagoing boats and existence of a well-developed boat technology (Bjerck 2009:125).

\section{Skin boats and $\log$ boats}

Despite the acceptance of a maritime settlement model necessitating seaworthy vessels, the question of what sort of boats were involved and their degree of importance in colonizing seascapes remains a contested topic in the absence of boat remains. Long-standing and emotionally charged squabbling about the relative importance of skin boats and $\log$ boats can be traced back to a unilineal cultural evolutionary perspective regarding the origin of plank-built boats within Scandinavian maritime archaeology in the 1970s (Crumlin-Pedersen 1972).

Glørstad (2013) revitalized the skin vs. log boat debate through an advocacy of log boats to support a 'boreal perspective' characterized by cautious, gradual exploration of the coast in the Early Mesolithic. As Bjerck (2013) rightly observed and criticized, Glørstad's main point is that boats were 'simple' and had only moderate seagoing abilities with use restricted to 'small-scale' sea traffic. Glørstad attacks skin boat proponents such as Bjerck (2009) for supporting a model of rapid settlement by small, highly mobile maritime groups dependent on skin boat technology as well as misuse of ethnographic analogy in comparing Mesolithic skin boats to the umiak. This last criticism is echoed by Reide and Tallavaara (2014:4-5) with the questionable assertion that arguments for fully marine technologies and adaptations by the end of the Lateglacial "rob these prehistoric hunter-gatherers of their own history, and would indeed turn them into little more than pale reflections of the more detailed ethnographic record." Although some responses to Glørstad's (2013) discussion article dismissed the potential of log boats (Bang-Anderson 2013), others maintained a more balanced perspective by pointing out the likelihood that a variety of boat types coexisted in the Mesolithic. 
Bjerck (2016) has elaborated upon an explicitly 'boatcentric' model emphasizing a total dependency on boats for continuous movement between temporary settlements in which islands played a critical role in accessing marine resources dominated by seal hunting in the Early Mesolithic. He argues that seafaring, transport and hunting activities were restricted to a single skin boat type resembling the Arctic umiak, based in part on a lack of sizable trees for log boat construction (Bjerck 2016: 285-286). It is clear that seaworthy boats were a prerequisite for colonization of the coast and the skin boat vs. log boat debate reflects an unnecessarily myopic approach. It is also justifiable to assume that a variety of watercraft were in use, including both skin and log boats adapted to specific marine and freshwater environments and conditions.

\section{Boats written in stone: rock art and reality in the first millennium BC}

Depictions of boats are a central carved rock art element in Fennoscandia from c. 5000 BC until the end of the first millennium $\mathrm{BC}$ when this medium was generally replaced by other forms of expression. The recent discovery of what may be the world's earliest boat petroglyph, at Valle in Ballangen, northern Norway (Trygstad and Mikalsen 2017), offers a unique insight into watercraft from the Early Mesolithic. Although presently $72 \mathrm{~m}$ asl, if originally situated near the shoreline as is generally the case with this type of rock art, the figure is estimated to have been produced around 10,000 BP on the basis of shoreline dating (Hesjedal 1994:4). The figure consists of a ground linear outline of a boat c. 4.3 meters in length with a characteristic gunwale extension in the bow closely resembling a full-sized (6-10 meters) umiak open skin boat and is arguably a 'smoking gun' for the skin boat colonization model (Figure 1). Ground rock art is the earliest petroglyph style in Norway and restricted to two areas along the coast of Nordland (Hesjedal 1994). This type of petroglyph is characterized by large-scale naturalistic representations of animals (reindeer, bears, birds, seals, whales) with the Ballangen boat being the only known example of a non-animal motif.

The focus in this article is on carved boat images spanning the first millennium BC in Scandinavia where rock art remains a key source of information on the physical appearance of boats through the Pre-Roman Iron Age (500-0 BC). Kaul (1998) proposed a new sequence for the chronological typological development of Nordic Bronze Age ship images on stone based on datable ship renderings from bronze artefacts, particularly razors, in southern Scandinavia. This chronology ends at the beginning of the PreRoman Iron Age when Kaul (2004:122) asserts that ship iconography almost disappears. However, it is acknowledged that a few rock carvings, mostly in Bohuslän, western Sweden, Stjørdal, North Trøndelag, Norway and on the island of Bornholm, Denmark, occur during this period. These ships are symmetrical with slightly curved hulls and keel and gunwale extensions and, according to Kaul, exactly the same profile-shape as the Hjortspring vessel (Kaul 2004:133-134). Sognes (2006, 2008) takes issue with Kaul's assertion that post-Bronze Age rock art boats are few and insignificant by citing evidence from Stjørdal in central Norway where late (Iron Age) boat types predominate. Sognes identifies two late boat types, Hjortspring and Austreheim, as well as a hybrid where the former has been transformed into the latter.

These boat types also appear at the Dalbo rock art site near Oslo where they represent a deviation from the remainder of southeast Norway (Sognes 2006:181). The typological chronology of Bronze Age to early Iron Age ships is built upon a number of independent dating methods, including well-dated ship images on Bronze Age bronzes (Kaul 1998), shoreline dating (Ling 2014), and the superimposition and modification of rock carvings over time (Sognes 2008). However, this relative chronology is handicapped by diffuse, imprecise boundaries between 'boat types' when compared to the potential of actual boat remains with absolute dates.

There is ongoing debate as to whether boats are more 'real' than other rock art images and the degree to which they reflect intertwined representations depicting both real and cosmological realities in 
Scandinavia (Helskog 2012; Gjerde 2016). Considerable scholarly attention has been focused on rock art as a means of expressing the role of the ship as a prominent, or even paramount, symbol in the (South) Scandinavian Bronze Age where voyaging is viewed as means of achieving status and renown within stratified chiefdoms (Kristiansen 2004; Kvalø 2004). The fact that rock art scholars consistently refer to images of Stone Age watercraft as 'boats' in contrast to Bronze Age 'ships' illustrates the increased status attributed to vessels as expressions of Bronze Age chiefly power. While the importance of regional and local variation in ship images has been recognized, it is often framed within the context of voyaging chiefs. The shift to symmetric vessels such as Hjortspring in the Pre-Roman Iron Age is seen as reflecting a drastic change in social and religious perceptions of the ship from a symbol of the sacred to secularized performance as a vehicle of war (Kaul 2004). Ling (2014) rejects the pervasive view of Bronze Age rock art ships as expressions of power monopolized by chiefs in the rock art region of Bohuslän. His alternative perspective emphasizes individual agency by a maritime population linked to long-distance expeditions. The rock art is viewed as a vehicle for projections through a highly formalized medium that represents a warped reflection of a real social world (Ling and Cornell 2010: 40).

To what degree do the boat types depicted in Nordic Bronze Age and Pre-Roman Iron Age rock art extend into northern Norway? The only location in Arctic Norway with boats of comparable age is a restricted area of the Alta rock art complex on the coast of western Finnmark. Attempts to identify Nordic Bronze Age rock art boats in the far north have been heavily influenced by an agricultural frame of reference for rock art extending from South Scandinavia as far north as Trøndelag in central Norway and the nonagricultural context of Alta is problematic in this regard (Helskog 2012; Kaul 2014). The northernmost potential outpost of Nordic Bronze Age settlement is a short-term occupation site from 1000-800 BC at Sandvika near the northern cereal limit in Troms, a considerable distance south of Alta (Jensen and Arntzen 2016). Although the limited corpus of boats younger than c. $1700 \mathrm{BC}$ at Alta do include some figures resembling those further south in Scandinavia (Kaul 2014), these must be interpreted within a hunter-fisher-gatherer cultural context (Figure 2). The 16 boat images potentially dating to the Pre-Roman Iron Age at Alta have the most varied morphology and symmetric vessels with projecting keel and gunwale resembling the Hjortspring boat are lacking. There is, however, at least one boat that appears to have a steering oar (Figure 2, bottom left). Helskog (2012) asserts that the boat types suggest contact with agricultural settlements to the south and reflect the introduction of new technology including larger vessels capable of long-distance sea voyages. An overall assessment suggests that similarities in rock art boats between north and south were a result of shared nautical templates reflecting widespread networks of maritime interaction that transcended subsistence and cosmology.

Boat remains in Scandinavia predating the Iron Age include log boats dating back to the Mesolithic in Denmark and the Bronze Age on the Scandinavian Peninsula (Lanting 2000; Kastholm 2015) and a bark canoe from Byslätt in south-western Sweden recently dated to 900-800 BC (Von Arbin and Lindberg 2017). These vessels were arguably designed for inland waters or nearshore use. Kastholm (2015) has demonstrated that a considerable number of Bronze Age log boats have features that mimic plank-built boats as yet undocumented outside Britain, thus signaling participation in a larger maritime network (Van de Noort 2006). The earliest remains of a true seagoing vessel in Scandinavia is the Hjortspring boat from southern Denmark dated to c. 350 BC (Crumlin-Pedersen and Trakadas 2003; Kaul 2003a). This extremely slender $19 \mathrm{~m}$ long wooden war canoe has an expanded bottom with sewn side strakes and was deposited in a bog as part of a war booty sacrifice. It has a distinctive symmetrical form with beaks at both ends formed by the bottom plank and gunwale extending beyond the hull that is similar in profile to 'late ship' rock carvings assigned to the early Pre-Roman Iron Age that are especially common in Bohuslän, western Sweden and Trøndelag, central Norway (Kaul 2003a, b). Being the only existing reconstructable plank-built boat from the Pre-Roman Iron Age, it is legitimate to question whether the Hjortspring vessel, 
a highly specialized paddled war canoe deposited in a ritual context, represents a common boat type from this period. Despite this uncertainty, rock art scholars (Kaul 2003a; Coles 2007) have argued that Hjortspring type boats were commonplace, if not dominant, in the mid-first millennium BC based solely on the iconographic evidence.

There is a single carved boat figure indicating the presence of rowed vessels in southern Scandinavia during the Pre-Roman Iron Age. Østmo $(1992,2014)$ has long argued that a rock art boat from Dalbo near Oslo, Norway (Figure 3) represents the earliest example of rowing in Scandinavia and is the only certain case of rowing from a rock art vessel. According to Østmo (2014: 265-266), although clearly from the Nordic Bronze Age tradition, the image depicts a Hjortspring type boat "without a doubt being rowed". Ten long oars extend at an angle along the side of the vessel accompanied by steering oars at both ends. As Østmo admits, the precise dating of the figure is difficult to confirm but is most likely from the late Pre-Roman Iron Age. For Østmo, the Dalbo boat demonstrates that rowing appeared while ships were still built in the Bronze Age manner and must have been a thorough and swift transition. Although the depiction of oars on the Dalbo boat is convincing, the likelihood of a Hjortspring type vessel being rowed is more problematic. The hull form and construction of this plank-built slender canoe is not compatible with rowing which necessitates a more robust hull construction and use of natural grown frames. It is possible that the oar strokes were added to a Bronze Age boat during the Pre-Roman Iron Age in order to update or upgrade the earlier image, as has been observed for a number of rock carvings in Scandinavia (Kaul 2003b; Sognnes 2008; Kaul 2014:118). Such actions have been interpreted as both a sign of ancestral respect and an intentional defacing of earlier images. In this case, the potential alterations may have been a way of synthesizing Bronze Age and Pre-Roman Iron Age realities into a nonexistent hybrid symbolic vessel.

\section{Boats from bogs: Early Iron Age boat remains from Arctic Norway}

A project undertaken by the author has examined potential pre-modern wooden boat parts and boat related remains recovered from bogs in northern Norway housed at The Arctic University Museum of Norway, all found within the Arctic Circle (Figure 4). The project focus has been on obtaining reliable radiocarbon age estimates for as many finds as possible in addition to detailed description and visual documentation. Dendrochronological age determinations were also possible for three of the boat finds.

Eighteen individual boat finds from 16 known locations and one unprovenienced object have been documented, all representing artifacts made of Scots pine (Pinus sylvestris) found by non-archaeologists. An additional three objects originally interpreted as boat finds, two spades of aspen mistakenly identified as paddles and a frame-like object of ash, were also analyzed and dated. Thirty radiocarbon dates have been obtained, all but four by AMS, including double dates from eight objects and single dates from four non-boat finds. Multiple radiocarbon age estimates utilized different dating facilities (Waikato, NTNU and Beta Analytic) making it possible to assess potential lab error. Dating samples from finds with suspected contamination due to conservation treatment (e.g. creosote, varnish) and other contaminants were treated by solvent extraction when dated. Additional dates processed with solvent extraction were obtained from objects with questionable or unexpectedly early initial age ranges.

As all of the boat remains consist of potentially long-lived pine, the 'old wood' effect can be significant. This is illustrated by the few finds for which additional dendrochronological age estimates were possible and a single find where dates for both wood and short-lived animal hair caulking were obtained. The age discrepancy in these cases was up to several centuries. In order to minimize the impact of inbuilt age, radiocarbon samples were collected from the outermost growth rings in consultation with a dendrochronologist. 
Nearly all of the analyzed finds were found by local residents during peat cutting for fuel and given to Tromsø Museum between 1886 and the 1950s with a majority $(n=7)$ discovered in the 1930s. The most recently accessioned finds date to the 1970s. Only two boat finds, both from the Viking Age, have been investigated archaeologically, the Bårset boat potentially representing a ritual deposition and Øksnes boat grave, both excavated in the 1930s (Gjessing 1941). The author surveyed nine find locations in order to provide information on provenance and depositional environments. A majority of the find contexts are interpreted as representing deposition in shallow water or the intertidal zone with subsequent development of overlying peat deposits. Other depositional contexts include a boat burial, three potential ritual offerings in bogs, a prehistoric boat landing, a possible boat repair site, and temporary storage of used boat parts.

The present discussion is restricted for the most part to six boat-related objects with age ranges predating the Late Iron Age (AD 550-1050), including two from the Migration Period (AD 400-550) and four from the Pre-Roman Iron Age (500-0 BC). Three paddles from the Bronze Age / Early Metal Age (1700-500 BC) and Late Stone Age (4000-1700 BC) are also discussed. The principle focus is on remains from the Pre-Roman Iron Age that have dramatically altered the current state of knowledge regarding early plankbuilt boats in Scandinavia. The Early Iron Age boat remains are from islands along the outer coast of Troms County and a single find from Nordland County. A majority of these locations lie along the outer shorelines of large islands or small offshore islands where seagoing vessels were essential for settlements dependent on marine resources. The find sites also represent a marked contrast from marine environments in southern Scandinavia and the western Baltic where sheltered, calm waters were far more common and open water distances significantly shorter.

\section{Pre-Iron Age paddles}

The three paddle finds predating the Iron Age were found in mainland coastal settings and represent the only known paddles of this age from Norway (Figure $5 \mathrm{a}-\mathrm{c}$ ). The earliest (Lyngmo, Troms - 2776-2580 cal BC) and most recent (Ropelv, Finnmark - 1302-1122 cal BC) paddles were deposited at the base of peat deposits near river mouths and the third (Hornneset, Nordland - 2581-2468 cal BC) near the intertidal zone of a shallow marine embayment. The paddles have shafts with similar oval cross sections from 2.2$3.3 \mathrm{~cm}$ and long, narrow ridged blades with the following dimensions; Lyngmo $(43.5+\mathrm{x} 10 \mathrm{x} 1 \mathrm{~cm})$, Hornneset $(41+\mathrm{x} 8 \times 1.1 \mathrm{~cm})$, Ropelv $(21+\mathrm{x} 4.3+\mathrm{x} 1.9+\mathrm{cm})$. The earliest paddle has distinct parallel ridges produced from thinning the blade with a slightly curved $5 \mathrm{~mm}$ wide tool. The paddle blades are well suited to long distance coastal travel in lightweight boats.

The three northern Norwegian paddles are similar to those from the Neolithic and Bronze Age in southern Scandinavia and northern Europe (Germany, eastern Baltic) with narrow blades better suited to long distance travel than the short and wide Mesolithic paddles found in Denmark (Burov 2000; Hartz and Lübke 2000). The Hjortspring paddle blades are narrow and short with dimensions encompassing those of the northern Norwegian paddles, ranging from $5.5-10 \mathrm{~cm}$ in width and $21-45 / 58 \mathrm{~cm}$ in length (CrumlinPedersen and Trakadas 2000).

\section{Early Iron Age boat frames}

\section{Grunnfarnes, Senja Island (598-402 cal BC)}

This is a lightweight boat frame fashioned from a naturally curved root and trunk segment of young pine with maximum dimensions of $9.5 \times 3.5 \mathrm{~cm}$ in the midsection (Figure 6). It has an interior width of $115 \mathrm{~cm}$ and height of $28 \mathrm{~cm}$ and is complete apart from $20 \mathrm{~cm}$ missing from the end of one arm that is reconstructable by mirroring the intact arm. The frame has six rectangular lashing holes $(2.1-3 \times 1 \mathrm{~cm}) \mathrm{cut}$ 
with a chisel-like tool for fastening planks that were also most likely lashed or sewn to one another. Assuming that the frame was attached to two cleats on each plank, there would only have been one strake with cleats above the bottom strake in addition to a sheer strake lacking cleats that was apparently lashed where there is a notch on the upper arm interior. The upper $25 \mathrm{~cm}$ of the arm exterior below the notch has been smoothed flat to accommodate the sheer strake.

The Grunnfarnes frame is the earliest physical evidence for a plank-built vessel in Scandinavia and potentially predates the Hjortspring canoe by at least half a century, based on radiocarbon dates from two labs. The use of a proper grown frame in contrast to the bent hazel branch ribs of the Hjortspring canoe is also a strong argument for use in a boat that was rowed rather than paddled. The earliest previous (indirect) evidence for the use of grown frames is a thwart from Hampnäs in northern Sweden dated to c. $200 \mathrm{BC}$ resembling the Hjortspring thwarts but with notches at the ends to accommodate a grown frame (Crumlin-Pedersen 2003: 221; Ramquist 2009). Pine boat planks with paired cleats from a bog at Haugvik in Helgeland, northern Norway, dated to 200-0 BC; further support the existence of plank-built boats with grown frames in the Pre-Roman Iron Age (Sylvester 2009). The Haugvik boat was originally dated to the Late Bronze Age but additional dating of the find and surrounding peat confirmed a more recent age. While the age discrepancies have been attributed to contamination from "a tar-like substance" applied by the finder (Sylvester 2009: 58), inbuilt age may also have been a contributing factor.

Børøya, Stokmarknes, Vesterålen archipelago (cal AD 422-574)

A pine frame fragment unearthed during construction work in a bog on the island of Børøya in 1974 was first described and radiocarbon dated to the Migration Period by Bertelsen (1976). A second date obtained by the author produced an unexpected early age range from the Pre-Roman Iron Age. Upon closer inspection, it was revealed that a substance resembling varnish had been applied to the frame at some point after recovery. A third date processed with solvent extraction produced an age range that harmonized well with the original date. The frame was shaped from a naturally curved root and trunk segment much heavier than the Grunnfarnes frame and belonging to a substantially larger vessel (Figure 7). Approximately half of the frame is present but the base appears to be warped outward giving the reconstructed profile a broad, flattened appearance.

As with the Grunnfarnes frame, planks would have been lashed to the frame with double cleats in contrast to Late Iron Age boats such as Kvalsund, dated to cal AD 651-779 (Table 2; Myhre 1980), with single cleats (Shetelig and Johannessen 1929). There are nine circular auger-bored lashing holes in the frame. The holes have a uniform diameter of $1.6 \mathrm{~cm}$ and were fire hardened leaving a blackened interior surface. Although speculative given the incomplete and potentially deformed state of the frame, there appears to have been three strakes above the bottom strake in addition to the sheer strake, which was fastened to the top of the frame with an iron rivet. However, an additional strake may have been present above the bottom strake. The top of the frame is flattened and decorated with intersecting groups of incised lines made by a 5-pronged tool that enclose a rectangular $2 \times 1.5 \mathrm{~cm}$ rivet rove impression (Figure 7 inset). It is also likely that the boat was clinker-built with planks fastened to one another by iron rivets.

The Børøya frame demonstrates continuity in plank boat construction from the Pre-Roman Iron Age with frames lashed to the strakes using double cleats. It also shares traits first documented in the three Nydam ships found near Hjortspring and sacrificed during the period AD 240-360. These vessels represent the earliest evidence of rowed clinker-built ships in Scandinavia and all have double cleats (Rieck 2003). The Halsnøy boat consists of the remains of about one-quarter of a small rowed vessel from a bog in western Norway radiocarbon dated to cal AD 325-550 (Table 2). It has strakes that are sewn together and lashed to frames with double cleats, a wide bottom strake, and rowlocks lashed to the sheer strake which Shetelig 
(1903: 8) described as "a very primitive construction" despite similarities to the Nydam ships. Although in need of multiple dates to provide a more precise age estimate, the Halsnøy boat does demonstrate the continued presence of sewn plank boats post-dating the Nydam ships and potentially contemporary with the Børøya boat.

\section{Pre-Roman Iron Age rowing oars}

Three bog finds from Arctic Norway interpreted as rowing or steering oars provide further evidence that rowed vessels were fully developed during the Pre-Roman Iron Age in Scandinavia (Figure 8). Two of the oars closely resemble one another in form with intact blades and partial shafts making it possible to estimate the entire oar length, and the third is a shaft fragment from a somewhat different type of oar.

Unknown provenance (536-392 cal BC)

This oar was discovered by the author in storage with the remains of the Viking Age Bårset boat at The Arctic University Museum of Norway. It is unclear when these remains were comingled but conservation of both finds with creosote suggests that the oar came to the museum in the 1930s and may also have originated in the northern Troms region. The $152 \mathrm{~cm}$ long oar blade and shaft fragment has a $102.5 \mathrm{~cm}$ long nearly complete spear-like ridged blade tapering from $9.3 \times 4.5 \mathrm{~cm}$ at the inner end to $6.3 \times 2.3 \mathrm{~cm}$ at the outermost complete profile point (Figure 8a). There is a distinctive $2.2 \mathrm{~cm}$ long tapered double notch at the transition from the blade to a c. $5.2 \times 4.3 \mathrm{~cm}$ faceted shaft segment extending $37.5 \mathrm{~cm}$ (Figure 9). The shaft bulges slightly above this segment where it has a rounded $4 \times 4 \mathrm{~cm}$ profile. There is evidence of heavy wear attributed to rowlock abrasion that may explain why the shaft is broken off at this point. Two statistically identical radiocarbon dates were obtained from the oar at different labs with solvent extraction for removal of creosote contamination. The dates are also contemporary with the Gunnfarnes frame thus strengthening the argument for rowed vessels predating the Hjortspring boat.

Hersøy Island, northern Troms (360-156 cal BC)

The Hersøy oar was given to Tromsø Museum in 1974 with an initial description and radiocarbon date from the Roman Iron Age (cal AD 71-264) provided by Bratrein (1989:148). A second radiocarbon date obtained by the author produced a significantly earlier age range (204-46 cal BC). As the oar was reportedly contaminated by fish oil when it arrived at the museum, a third radiocarbon date was processed with solvent extraction and produced an even earlier age range (360-156 cal BC). The collective dating results strongly indicate a Pre-Roman Iron Age association as do close similarities with the earliest oar.

The oar is $146 \mathrm{~cm}$ in length with a complete $107 \mathrm{~cm}$ long ridged oval blade that is $8.5 \mathrm{x} 2.5 \mathrm{~cm}$ at the distal end and tapers upward to a $5 \times 3.5 \mathrm{~cm}$ faceted profile (Figure $8 \mathrm{~b}$ and Figure $11 \mathrm{~b}$ ). A distinctive 2 $\mathrm{cm}$ long stepped double notch occurs at the transition from the blade to a c. $5 \times 2.7 \mathrm{~cm}$ faceted shaft segment that is $24 \mathrm{~cm}$ long (Figure 10). The profile is modified at this point to a rounded $5 \times 4.5 \mathrm{~cm}$ bulge that is reduced to $3.5 \mathrm{~cm}$ in the final $4 \mathrm{~cm}$. There are signs of wear attributed to rowlock abrasion that may have caused the shaft to break at precisely the same point as the earlier oar.

The University Museum of Norway's traditional boat builder Gunnar Eldjarn produced a copy of the Hersøy oar with a total length of $244 \mathrm{~cm}$. The missing portion of the shaft was reconstructed using a ratio of roughly $1 / 3$ for the inboard portion of the oar, although traditional Norwegian rowboats normally have a ratio of 1/4 (Figure 11a). The oar was tested in a traditional rowboat (fering) c. $5 \mathrm{~m}$ in length with two pairs of oars (Figure 12). Although the oar performed well, there was no practical advantage to the thinner shaft segment between the blade and rowlock, which made the oar somewhat clumsier to handle. 
The two oars are strikingly similar in overall form with long, narrow blades and a thinner segment of the shaft above the blade varying from 37 to $24 \mathrm{~cm}$ in length and bounded by a distinctive double notch where the blade terminates and a bulge below the rowlock contact point. The more recent oar may reflect a transition in blade form from an early pointed type to a narrow oval shape that is closer in form to later Iron Age oars. However, both oar blades are much longer $(104$ and $107 \mathrm{~cm})$ than Late Iron Age oars. These include the $3.47 \mathrm{~m}$ complete rowing oar from the Bårset boat (AD 850-900) which has a $65 \mathrm{~cm}$ long blade (Figure 11c) and an oar blade found in a bog at Bøtneset in northern Troms (cal AD 770-898) that is $47 \times 13 \mathrm{~cm}$ (Figure 5d). Rowing oars from the Viking Age display a significant degree of standardization that continues into the historic period.

Why do the oars have such long, thin blades with an impractical thinned shaft segment above? One possibility is that they served as oars for steering rather than rowing on rowed vessels, such as the steering oars depicted on the Dalbo rock carving and a potential late boat image from Alta. If the northern Norwegian oars were for steering, they must have been fastened to the hull in a similar manner as later side rudders, such as those on the Nydam ships, in order to explain the wear attributed to rowlock abrasion. Steering oars also appear on a number of other Hjortspring type boat carvings representing paddled boats, but these are unlikely to have been fastened to the hull. The thinned oar shaft segments with notched margin may have served a decorative rather than practical function with such expressions potentially more common on oars for steering rather than rowing, where they would be more of a hindrance than an asset.

\section{Hofsøy, Senja Island (232-54 cal BC)}

An oar shaft fragment was recovered in 1956 from near the base of a $2 \mathrm{~m}$ thick peat layer that would have been c. $1 \mathrm{~m}$ asl at the time of deposition. The oar shaft had been placed between, and perpendicular to, two parallel rows of stones interpreted by the finder as marking the margins of a boat landing feature. The oar shaft is $97.5 \mathrm{~cm}$ long and had been intentionally cut off at both ends (Figure 8c). A $19 \mathrm{~cm}$ long thinned and flattened hexagonal $5 \times 2 \mathrm{~cm}$ segment with $2 \mathrm{~cm}$ wide facets at one end of the shaft is interpreted as potentially representing the same type of thinned shaft segment located above the blade on the other two oars. The upper shaft has a rounded profile that tapers gradually from $5.2 \mathrm{~cm}$ to $3 \mathrm{~cm}$ at the upper end. The entire shaft is heavily worn due to potential secondary use as a boat landing skid as described by the finder. A shallow $4 \mathrm{~cm}$ wide groove in the shaft $53 \mathrm{~cm}$ from the upper end is also most likely from secondary use rather than rowlock abrasion.

\section{A Migration Period rowlock from Stonglandseidet, Senja Island (cal AD 396-542)}

Rowlock traits have been utilized as typological indicators of relative age in the first millennium AD (Christensen 1995). An early type associated with vessels such as Nydam and Halsnøy is lashed to the sheer strake and has triangular chiseled grommet holes below and in front of the horn. Late Iron Age rowlocks from Kvalsund and later boats are attached by treenails with auger-bored grommet holes placed in front of the horn. Christensen (1995) has classified rowlocks from the Mangersnes boat repair bog site in western Norway, including the earliest dated rowlock from Norway (c. 30 BC - AD 250), into Nydam and Kvalsund groups using these traits.

A rowlock from the island of Senja in Troms with two statistically identical radiocarbon dates provides insight into the nature of rowed vessels in northern Norway near the end of the Early Iron Age (Figure 13). It is fashioned from a lightweight naturally curved root and trunk segment with polished surfaces from long use. The rowlock measures $13.5 \mathrm{~cm}$ in height, 10.5 in length and is $2.3-2.6 \mathrm{~cm}$ thick. The basal portion of the rowlock that would reveal the fastening method is missing, but the presence of a $1.3 \mathrm{~cm}$ auger-bored grommet hole in front of the horn is claimed to be an Early Iron Age trait. 


\section{The rowing revolution: comparisons between north and south}

The transition from paddling to rowing represents a revolutionary transformation of boat technology in Scandinavia arguably of equal importance to the introduction of sails. Although it is widely accepted that sails were first used in Scandinavia during the Late Iron Age, most likely in the 8th century AD (Westerdahl 1995, 2015), there are some who claim a much earlier introduction based on features resembling a mast or sail on Bronze Age rock art boats (Bengtsson and Bengtsson 2011). The introduction of rowing made possible dramatic increases in the size, carrying capacity, speed and seagoing capabilities of boats. As argued here based on boat parts including a frame and multiple oars, the earliest evidence for rowing in Scandinavia originates from islands facing the open sea in Arctic Norway. This demonstrates the importance of rowed boats for seagoing communication and interaction essential to maintaining maritime communities in a sea of islands. If rowed plank-built vessels were fully developed early in the Pre-Roman Iron Age in northern Norway, can it also be assumed that they were commonplace by this time in southern Scandinavia? How do the Hjortspring boat and rock carvings of vessels with a similar appearance fit into this picture? A Hjortspring type canoe with its protruding beaked appendages and flimsy bent branch ribs does not have a hull form or strength that lends itself to being rowed, even if this may have been technically possible.

The Hjortspring boat developed out of a Bronze Age boatbuilding tradition with deep ancestral roots (Austvoll 2018). It can also be viewed as an archaic instrument through which a warrior elite continued to symbolically legitimize their power within the altered sociocultural circumstances of the Pre-Roman Iron Age. Perhaps this is why the Hjortspring canoe was singled out for such thorough ritual destruction. Hjortspring type boats have also played a key role in modeling societal transformation from a Bronze Age maritime focus on exchange of valuables to an Iron Age emphasis on warfare and control of land (Kaul 2003a; 2004). If this type of vessel is atypical, should it be used to support these generalized models?

Is the only example of a rowed rock art vessel, the potentially upgraded boat from Dalbo, a late attempt to harmonize past and present or did rowed vessels maintain some Hjortspring-like traits? Perhaps this image represents an attempt by southern Scandinavians to record an encounter with exotic rowed boats from the north in a reversal of the process whereby elements of boat design carved into rock are claimed to have been diffused northward to the extreme margins of the civilized (agricultural) world. A more likely maritime scenario during the Pre-Roman Iron Age in southern Scandinavia is that a wide assortment of vessels plied the coasts and islands, including plank-built vessels that were both rowed and paddled as well as $\log$ boats.

\section{Concluding thoughts}

It is essential to acknowledge the proficiency of northern Norwegian maritime communities who possessed the necessary boat technology and seamanship by the Early Mesolithic to bind together a sea of islands into coherent units of maritime interaction and culture. The documentation of boat remains from bogs in Arctic Norway provides significant insights into both pre-Iron Age and Early Iron Age boat technology and demonstrates the proficiency of islanders and coastal communities in mastering their seacentered existence. The predominance of boat finds from offshore islands and the outer coast underlines the centrality of these seascapes that have been increasingly marginalized in contemporary society. The central role played by smaller, offshore islands in maritime systems is particularly evident. The degree of connectedness between islands and the coastal mainland has also been revealed through the bog boat project.

The new evidence presented here has revealed that rowed plank-built vessels were in use at the start of the Iron Age in northern Norway. These developments can be assumed to apply elsewhere in Scandinavia and 
necessitate a rethinking of current perceptions of boat technology developed in the southern margins. The combined evidence of a boat frame and oars from the Pre-Roman Iron Age has provided us with a tantalizing glimpse into previously unknown aspects of boat technology during a critical formative period in which paddling was replaced by rowing as the dominant means of propulsion. The bog boat evidence also reinforces the assertion that our current thinking consistently underestimates the level of nautical proficiency and sophistication of watercraft since the colonization of Scandinavian seascapes.

Compliance with Ethical Standards:

Conflict of Interest: The author declares that there is no conflict of interest.

\section{References}

Austvoll, KI (2018) Seaways to complexity. A study of sociopolitical organisation along the coast of Northwestern Scandinavia in the Late Neolithic and Early Bronze Age. Ph.D. Dissertation, Department of Archaeology, Conservation and Ancient History. University of Oslo, Norway

Bang-Andersen, S (2013) Missing boats - or lacking thoughts? Comments to Håkon Glørstad: 'Where are the missing boats?' Norwegian Archaeological Review 46(1):81-83

Bengtsson, B and Bengtsson, B (2011) Sailing rock art boats. Journal of Maritime Archaeology 6:37-73.

Bertelsen, R (1976) Viktig funn av båtspant på Børøya, Stokmarknes. Hofdasegl - Hadsel Historielag Årbok 21:891-894

Bjerck, HB (2009) Colonizing seascapes: comparative perspectives on the development of maritime relations in Scandinavia and Patagonia. Arctic Anthropology 46(1-2):118-131

Bjerck, HB (2013) Looking with both eyes. Comments to Håkon Glørstad: 'Where are the missing boats?'. Norwegian Archaeological Review 46(1):83-87

Bjerck, HB (2016) Settlements and seafaring: reflections on the integration of boats and settlements among marine foragers in Early Mesolithic Norway and the Yámana of Tierra del Fuego. Journal of Island and Coastal Archaeology 12(2):276-299

Bratrein, HD (1989) Karlsøy og Helgøy bygdebok: folkeliv, næringsliv, samfunnsliv: bind 1 Fra steinalder til år 1700. Karlsøy Municipality, Hansnes

Bronk Ramsey, C (2009) Bayesian analysis of radiocarbon dates. Radiocarbon 51(1):337-360

Burov, GM (2000). Inland waterborne trade of Baltic region inhabitants with communities of the Urals area in the Mesolithic and Neo-Eneolithic. In: Schutz des kulturerbes unter wasser. Veruderungen europischer lebenskultur durch fluss- und seehandel. IKUWA 1999. Beiträge zur Ur und Frühgeschichte Mecklenburg-Vorpommerns 35. Lübstorf, Germany, pp 21-34

Christensen, AE (1995) Boat fragments from Mangersnes. In: Olsen, O, Madsen, JS and Rieck, F (eds) Shipshape: Essays for Ole Crumlin-Pedersen. The Viking Ship Museum, Roskilde, pp 73-80

Coles, J (2007) Pre-Roman Iron Age boats and rocks in the north: reality and reflection. In: Gosden, C, Hamerow, H, De Jersey, P and Lock, G (eds) Communities and connections: essays in honour of Barry Cunliffe. Oxford University Press, Oxford, pp 43-53 
Crumlin-Pedersen, O (1972) Skin or wood? A study of the origin of the Scandinavian plank-boat. In: Hasslöf, O, Henningsen, $\mathrm{H}$ and Christensen, AE (eds) Ships and shipyards, sailors and fishermen. Introduction to maritime ethnology. Copenhagen, pp 208-234

Crumlin-Pedersen, O (2003) The Hjortspring boat in a ship-archaeological context. In: Crumlin-Pedersen, $\mathrm{O}$ and Trakadas, A (eds) Hjortspring. A Pre-Roman Iron-Age warship in context. (Ships and boats of the north. volume 5), The Viking Ship Museum, Roskilde, pp 209-232

Crumlin-Pedersen, O and Trakadas, A (eds) (2003) Hjortspring. A pre-Roman Iron-Age warship in context (Ships and Boats of the North 5). The Viking Ship Museum, Roskilde

Gjerde, JM (2016) Marine ventures in the Stone Age rock art of Fennoscandia. In: Bjerck, HB, Breivik, HM, Fretheim, SE, Piana, EL, Skar, B, Tivoli, AM and Zangrando, AFJ (eds) Marine ventures. Archaeological perspectives on human-sea relations. Equinox, Sheffield, pp 337-354

Gjessing, G (1941) Båtfunnene fra Bårset og Øksnes: To nordnorske jernalderfunn. Tromsø Museums Årshefter, Kulturhistorisk avd. nr. 8, Vol. 58

Glørstad, H (2013) Where are the missing boats? The pioneer settlement of Norway as long-term history. Norwegian Archaeological Review 46(1):57-80

Glørstad, H (2014) Deglaciation, sea-level change and the Holocene colonization of Norway. In: Harff, J, Bailey, G and Lüth, F (eds) Geology and archaeology: Submerged landscapes of the continental shelf. Special Publications No. 411. Geological Society, London, pp 9-25

Hartz, S and Lübke, H (2000) Stone Age paddles from northern Germany - basic implements of waterborne subsistence and trade. In: Schutz des kulturerbes unter wasser. Veruderungen europischer lebenskultur durch fluss- und seehandel. IKUWA 1999. Beiträge zur Ur und Frühgeschichte Mecklenburg-Vorpommerns 35. Lübstorf, Germany, pp 377-387

Helskog, K (2012) Helleristninger av båter og ressursutnyttelse i Europas nordlige ytterkant. In: Kaul, F and Sørensen, L (eds) Nordlige verdener - agrarsamfundenes ekspansion i nord. (Symposium på Tanums Hällristningsmuseum, Underslös, Bohuslän, 25-29.maj 2011). National Museum, Copenhagen, pp 221232

Hesjedal, A (1994) The hunters' rock art in Northern Norway. Problems of chronology and interpretation. Norwegian Archaeological Review 27(1):1-14

Jensen, CE and Arntzen, JE (2016) A Late Bronze Age sheep farm north of the Arctic Circle? In: Iversen F and Petersson, H (eds) The agrarian life of the North 2000 BC - AD 1000. Studies in rural settlement and farming in Norway. Portal Academic, Norway, pp. 173-202.

Kastholm, OT (2015) Plankboat skeuomorphs in Bronze Age logboats: a Scandinavian perspective. Antiquity 89(348):1353-1372

Kaul, F (2003a) The Hjortspring find. The oldest of the large Nordic war booty sacrifices. In: Jørgensen, L, Storgaard, B and Thomsen, LG (eds) The spoils of victory - the north in the shadow of the Roman empire, National Museum, Copenhagen, pp 212-223

Kaul, F (2003b) The Hjortspring boat and ship iconography of the Bronze Age and Early Pre-Roman Iron Age. In: Crumlin-Pedersen, O and Trakadas, A (eds) Hjortspring. A Pre-Roman Iron-Age warship in context. (Ships and Boats of the North. Volume 5), The Viking Ship Museum, Roskilde, pp 187-207 
Kaul, F (2004) Social and religious perceptions of the ship in Bronze Age Northern Europe. In: Clark, P (ed) The Dover boat in context. Society and water transport in prehistoric Europe. Oxbow Books, Oxford, pp. 122-137

Kaul, F (2014) The northernmost rock carvings belonging to the Scandinavian Bronze Age tradition. In: Gulløv, HC (eds) Northern worlds - landscapes, interactions and dynamics. Research at the National Museum of Denmark. Proceedings of the Northern Worlds Conference Copenhagen 28-30 November 2012, PNM Publications from the National Museum Studies in Archaeology and History Vol. 22. National Museum, Copenhagen, pp 115-128

Kristiansen, K. (2004) Sea faring voyages and rock art ships. In: Clark, P (ed) The Dover boat in context. Society and water transport in prehistoric Europe. Oxbow Books, Oxford, pp. 111-121

Kvalø, F (2004) Facing the sea in Bronze Age Norway: the ship, the sea and society. In:

Clark, P (ed) The Dover boat in context. Society and water transport in prehistoric Europe. Oxbow Books, Oxford, pp. 148-152

Lanting, JN (2000) Dates for origin and diffusion of the European logboat. Palaeohistoria 39/40 (1997/1998):627-650

Ling, J (2014) Elevated rock art: towards a maritime understanding of rock art in Northern Bohuslän, Sweden. Oxbow Books, Oxford

Ling, J and Cornell, P (2010) Rock art as secondary agent? Society and agency in Bronze Age Bohuslän. Norwegian Archaeological Review 43 (1): 26-43

Myhre, B (1980) Ny datering av våre eldste båter. Arkeo - arkeologiske meddelelser fra Historisk Museum, Universitetet i Bergen:27-30

Ramquist, PH (2009) Hampnäs-toften. Tradition eller förnyelse? Arkeologi i Norr 11:93-114

Reid, F and Tallavaara, M (eds) (2014) The lateglacial and postglacial pioneer colonization of northern Europe - an introduction. In: Lateglacial and Postglacial Pioneers in Northern Europe. BAR International Series 2599. Archaeopress, Oxford, pp 3-10

Reimer, PJ, Bard, E, Bayliss, A et al (2013) IntCal13 and Marine13 Radiocarbon Age Calibration Curves 0-50,000 Years cal BP. Radiocarbon 55(4):1869-1887

Rieck, F (2003) The ships from Nydam bog. In: Jørgensen, L, Storgaard, B and Thomsen, LG (eds) The spoils of victory - the north in the shadow of the Roman empire. National Museum, Copenhagen, pp 296309

Rowley-Conwy, P and Piper, S (2016) Hunter-gatherer variability: developing models for the northern coasts. Arctic 69 (suppl. 1):1-14

Shetelig, H (1903) Fragments of an old boat from Halsnø. Notes from the antiquarian collection. Bergens Museums Aarbog 1903 No. 7:8-21

Shetelig, H and Johannessen, F (1929) Kvalsundfundet og andre norske myrfund av fartøier. Bergens Museums Skrifter. Ny Rekke Bind II. Nr. 2. 
Sognnes, K (2006). Derom tier berget: omkring slutten på den nordiske bergkunsten. Glørstad, H, Skar, B and Skre, D (eds) Historien i forhistorien. Festskrift til Einar Østmo på 60-års dagen. Kulturhistorisk Museum, Universitetet i Oslo Skrifter 4, 2006, pp. 173-182

Sognnes, K (2008) Stability and change in Scandinavian rock art. The case of Bardal in Trøndelag, Norway. Acta Archaeologica 79: 230-245

Sylvester, M (2009) The Haugvik boat-a Pre-Roman Iron Age boat find from northern Norway. In: Bockius, R (ed) Between the seas: transfer and exchange in nautical technology. Proceedings of the 11th International Symposium on Boat and Ship Archaeology (ISBSA), September 2006, Mainz, Germany. RGZM-Tagungen 3. Verlag des Römisch-Germanischen Zentralmuseums, Mainz, pp 53-59

Trygstad, A and Mikalsen, K (2017) Sensasjonelt funn: Dette er trolig verdens eldste avbildning av båt. NRK Nordland 26 September 2017. https://www.nrk.no/nordland/sensasjonelt-funn_-_-dette-er-troligverdens-eldste-avbildning-av-bat-1.13706728 Accessed 30 November 2018

Van de Noort, R (2006) Argonauts of the North Sea - a social maritime archaeology for the 2nd Millennium BC. Proceedings of the Prehistoric Society 72:267-287

Van de Noort, R (2011) North Sea archaeologies: a maritime biography, 10,000 BC - AD 1500. Oxford University Press, Oxford

Von Arbin, S and Lindberg, M (2017) News on the Byslätt bark 'canoe'. In: Litwin, J (ed) Baltic and beyond. Change and continuity in shipbuilding. Proceedings of the 14th ISBSA symposium Gdańsk 2015. National Maritime Museum, Gdańsk, pp 245-250

Westerdahl, C (1995) Society and sail. On symbols as specific social values and ships as catalysts of social units. In: Crumlin-Pedersen O, Munch Thye B (eds) The ship as symbol in prehistoric and medieval Scandinavia. Studies in Archaeology and History 1. National Museum of Denmark, Copenhagen, pp. 4150.

Westerdahl, C (2015) The Viking ship in your mind. Some comments on its cognitive roles. Norsk Maritimt Museum Årbok 2014:33-69

Østmo, E (1992) Helleristninger i et utkantstrøk. Bidrag til skipshistorien fra nye jernalderristninger på Dalbo i Bærum. Varia 24. Museum of Cultural History, University of Oslo, Oslo

Østmo, E (2014) Shipbuilding and aristocratic splendor in the north, 2400 BC - 1000 AD. In: Gulløv, HC (ed) Northern worlds - landscapes, interactions and dynamics. Research at the National Museum of Denmark. Proceedings of the Northern Worlds Conference Copenhagen 28-30 November 2012. PNM Publications from the National Museum Studies in Archaeology and History Vol. 22. National Museum, Copenhagen, pp 257-272

\section{List of figures}

Figure 1. The Valle III (ID 246943) rock art boat from Ballangen, Nordland, northern Norway. Upper photo: boat with superimposed outline (Jan Magne Gjerde, The Arctic University Museum of Norway). Lower photo: overview of the boat taken from the bow end (Ingrid Sommerseth, The Arctic University Museum of Norway). 
Figure 2. Rock carvings of boats from the second and first millennium BC at Alta, Finnmark. Karin Tansem, World Heritage Rock Art Centre - Alta Museum.

Figure 3. Rock carving of a boat with rowing and steering oars from Dalbo (II/8) in Bærum, Akershus County, Norway (redrawn from Østmo 1992: Fig. 6). Adnan Icagic, The Arctic University Museum of Norway.

Figure 4. Map showing locations from northern Norway mentioned in the text. Adnan Icagic, The Arctic University Museum of Norway.

Figure 5. Stone Age and Bronze Age / Early Metal Age paddles from a) Lyngmo, Troms b) Hornneset, Nordland c) Ropelv, Finnmark and d) a Viking Age rowing oar blade from Bøtnes, Troms. Adnan Icagic, The Arctic University Museum of Norway.

Figure 6. Boat frame from Grunnfarnes, Senja Island in Troms with suggested reconstruction. Adnan Icagic, The Arctic University Museum of Norway.

Figure 7. Boat frame fragment from the island of Børøya, Stokmarknes, Nordland with suggested reconstruction and detail inset of upper arm with inscribed linear decoration and rove impression. Adnan Icagic, The Arctic University Museum of Norway.

Figure 8. Pre-Roman Iron Age oars: a) unknown provenance, b) Hersøy, Troms, c) Hofsøy, Troms. Adnan Icagic, The Arctic University Museum of Norway.

Figure 9. Detail view of Pre-Roman Iron Age oar shaft with unknown provenance. Adnan Icagic, Tromsø Univerity Museum.

Figure 10. Detail view of the Pre-Roman Iron Age oar shaft from Hersøy. Adnan Icagic, Tromsø Univerity Museum.

Figure 11. a) Photograph of a copy of the Hersøy oar with reconstructed shaft, b) Photograph of the original Hersøy oar fragment, c) Line drawing and photograph of Viking Age Bårset boat rowing oar. Adnan Icagic, The Arctic University Museum of Norway.

Figure 12. Photograph of Hersøy oar copy being used in a traditional northern Norwegian rowboat (foring). Gunnar Eldjarn, The Arctic University Museum of Norway.

Figure 13. Photograph of a rowlock from Stonglandseidet, Senja Island. Adnan Icagic, The Arctic University Museum of Norway. 


\section{Tables}

Table 1. Radiocarbon dates from northern Norwegian bog boat finds discussed in the text.

\begin{tabular}{|c|c|c|c|c|c|c|c|}
\hline $\begin{array}{l}\text { Catalog } \\
\text { no. (ts.) }\end{array}$ & Description $^{a}$ & Year & Location & Municipality & Lab no. & $\begin{array}{l}\text { Conventional } \\
\text { age }(\mathrm{BP})\end{array}$ & $\begin{array}{l}\text { Calibrated }{ }^{14} \mathrm{C} \text { age }(2 \\
\delta)^{\mathrm{b}}\end{array}$ \\
\hline 6353 & paddle & 1960 & Lyngmo & Kåfjord & Wk-30114* & $4124+/-29$ & $2776-2580 \mathrm{BC}$ \\
\hline 3710 & paddle & 1935 & $\begin{array}{l}\text { Hornneset, Sørfore } \\
\text { Øvre }\end{array}$ & Meløy & Beta-432341* & $4010+/-30$ & $2581-2468 \mathrm{BC}$ \\
\hline 15500 & paddle & 1957 & Ropelv & Sør-Varanger & TRa-2954* & $2995+/-30$ & $1302-1122 \mathrm{BC}$ \\
\hline 15499 & oar & $?$ & unknown & unknown & $\begin{array}{l}\text { Wk-30115*x } \\
\text { Beta-407523*x }\end{array}$ & $\begin{array}{l}2371+/-28 \\
2380+/-30\end{array}$ & $\begin{array}{l}536-392 \mathrm{BC} \\
541-392 \mathrm{BC}\end{array}$ \\
\hline 5480 & oar shaft & 1956 & Hofsøy & Tranøy & $\begin{array}{l}\text { TRa-2429* } \\
\text { Beta-407519* }\end{array}$ & $\begin{array}{l}2140+/-35 \\
2110+/-30 \\
\end{array}$ & $\begin{array}{l}232-54 \mathrm{BC} \\
204-46 \mathrm{BC}\end{array}$ \\
\hline 6369 & oar & 1974 & Hersøy & Karlsøy & $\begin{array}{l}\text { T-5652 } \\
\text { Beta-407521* } \\
\text { Beta-432342*x }\end{array}$ & $\begin{array}{l}1830+/-50 \\
2110+/-30 \\
2170+/-30\end{array}$ & $\begin{array}{l}\text { 71-264 AD (rejected) } \\
204-46 \mathrm{BC} \\
360-156 \mathrm{BC}\end{array}$ \\
\hline 5007 & frame & 1953 & Grunnfarnes & Torsken & $\begin{array}{l}\text { TRa-2427* } \\
\text { Beta-407518* }\end{array}$ & $\begin{array}{l}2455+/-30 \\
2420+/-30 \\
\end{array}$ & $\begin{array}{l}598-413 \mathrm{BC} \\
556-402 \mathrm{BC} \\
\end{array}$ \\
\hline 6746 & frame & 1974 & Børøya & Hadsel & $\begin{array}{l}\text { T- ? (1976) } \\
\text { Beta-424151*x } \\
\text { Beta-407522* }\end{array}$ & $\begin{array}{l}1600+/-60 \\
1550+/-30 \\
2260+/-30\end{array}$ & $\begin{array}{l}\text { 332-596 AD } \\
422-574 \mathrm{AD} \\
308-209 \mathrm{BC} \text { (rejected) }\end{array}$ \\
\hline 957 & rowlock & 1892 & Stonglandseidet & Tranøy & $\begin{array}{l}\text { Wk-30111* } \\
\text { Beta-407520* }\end{array}$ & $\begin{array}{l}1608+/-28 \\
1590+/-30\end{array}$ & $\begin{array}{l}396-537 \mathrm{AD} \\
406-542 \mathrm{AD}\end{array}$ \\
\hline $4145 \mathrm{a}$ & oar blade & 1939 & Bøtnes & Karlsøy & TRa-2425* & $1180+/-25$ & $770-898 \mathrm{AD}$ \\
\hline 3499 & $\begin{array}{l}\text { partially complete boat } \\
\text { with oar }\end{array}$ & 1931 & Bårset & Karlsøy & $\mathrm{T}-3802$ & $1080+/-80$ & $\begin{array}{l}\text { 768-1058 AD } \\
\text { dendro. 850-900 AD }\end{array}$ \\
\hline
\end{tabular}

a All dates obtained from wood samples of Scots pine (Pinus sylvestrus).

${ }^{\mathrm{b}}$ Bronk Ramsey 2009; Reimer et al. 2013. Calibrated with OxCal 4.2

* AMS / ${ }^{x}$ solvent extraction 
Table 2. Radiocarbon dates from Iron Age boat remains in Norway (Myhre 1980).

\begin{tabular}{|l|l|l|l|l|l|}
\hline Description & Location & Material & Lab no. & $\begin{array}{l}\text { Conventional age } \\
(\mathrm{BP})\end{array}$ & $\begin{array}{l}\text { Calibrated }{ }^{14} \mathrm{C} \text { age }(2 \\
\delta)^{\mathrm{a}}\end{array}$ \\
\hline $\begin{array}{l}\text { Valderøy boat, base of } \\
\text { grave mound }\end{array}$ & $\begin{array}{l}\text { Jangården, Giske, } \\
\text { Sunmøre }\end{array}$ & wood & T-644 & $1730+/-80$ & $83-430 \mathrm{AD}$ \\
\hline Halsnøy boat, bog find & $\begin{array}{l}\text { Tofte, Kvinnherad, } \\
\text { Hordaland }\end{array}$ & wood & T-3753 & $1630+/-50$ & $325-550 \mathrm{AD}$ \\
\hline $\begin{array}{l}\text { Holmedal boat, possible } \\
\text { grave in bog }\end{array}$ & $\begin{array}{l}\text { Fjaler, Sogn og } \\
\text { fjordane }\end{array}$ & wood & T-3754 & $1400+/-80$ & $506-774 \mathrm{AD}$ \\
\hline $\begin{array}{l}\text { Kvalsund (two boats), } \\
\text { bog find }\end{array}$ & Herøy, Sunnmøre & nettle & T-3755 & $1290+/-50$ & $651-779 \mathrm{AD}$ \\
\hline $\begin{array}{l}\text { Fjørtoft (two boats), } \\
\text { bog find }\end{array}$ & Haram, Sunnmøre & $\begin{array}{l}\text { textile } \\
\text { (caulking) }\end{array}$ & T-3752 & $1120+/-80$ & $688-1036 \mathrm{AD}$ \\
\hline
\end{tabular}

${ }^{a}$ Bronk Ramsey 2009; Reimer et al. 2013. Calibrated with OxCal 4.2 
Figure 1. Rock carvings of boats from the second and first millennium BC at Alta,

Finnmark. Karin Tansem, World Heritage Rock Art Centre - Alta Museum

\begin{tabular}{l} 
Bronze Age (2000-1000 BC) \\
$\begin{array}{l}11-13 \mathrm{~m} \text { asl } \\
\text { Bronze Age - Early Iron Age } \\
(1000-0 \mathrm{BC}) \\
9-11 \mathrm{~m} \text { asl }\end{array}$ \\
\hline $50 \mathrm{~cm}$
\end{tabular}




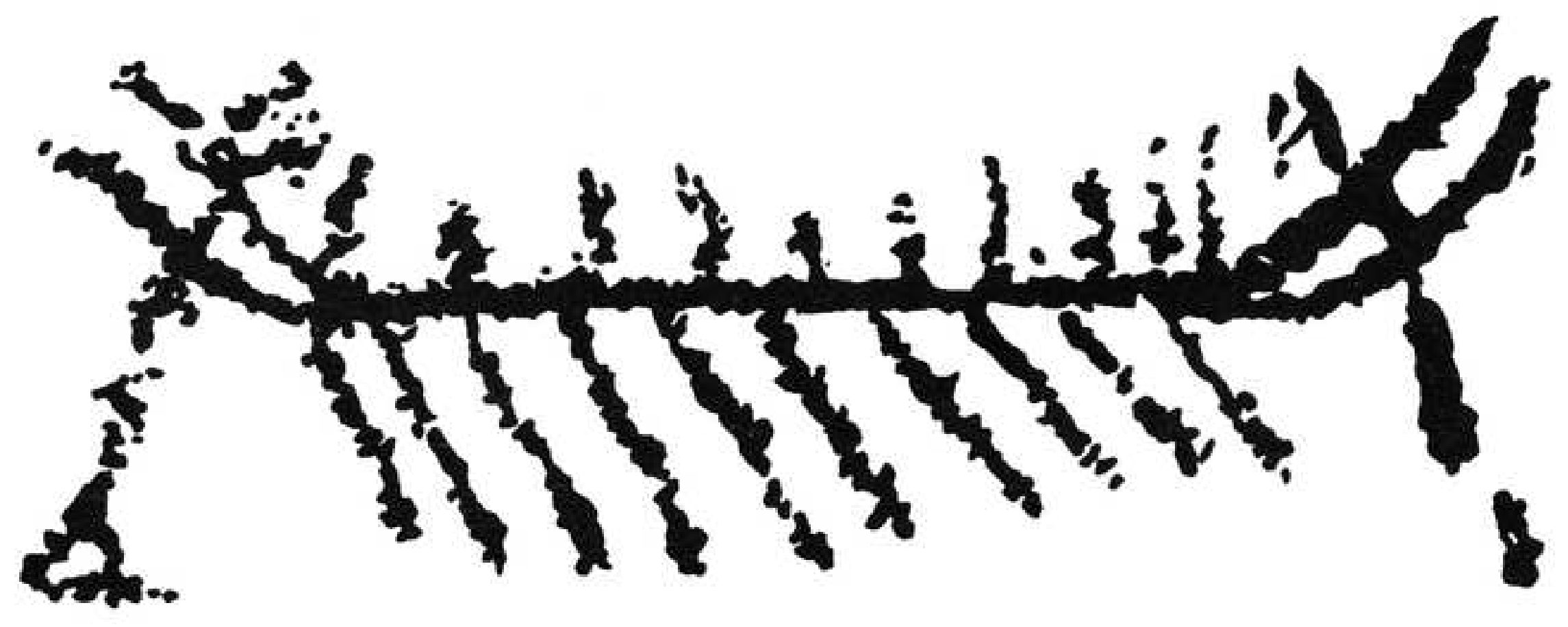


Figure 3. Map showing locations from northern Norway mentioned
in the text. Adnan Icagic, Troms $\varnothing$ Museum.

Figure 3 . Map showing locations from north
in the text. Adnan Icagic, Troms $\varnothing$ Museum.

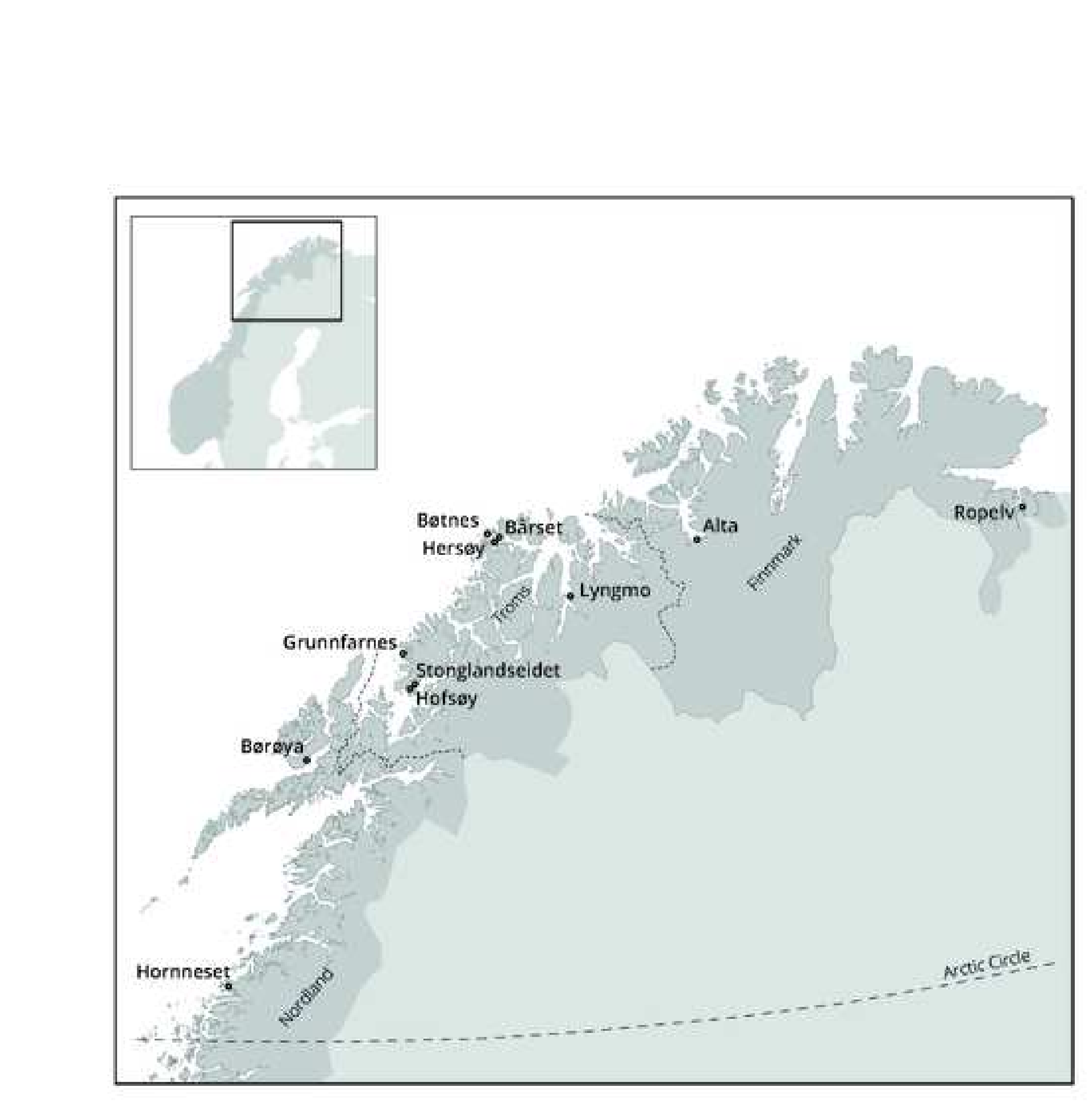

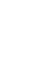

(1)

.
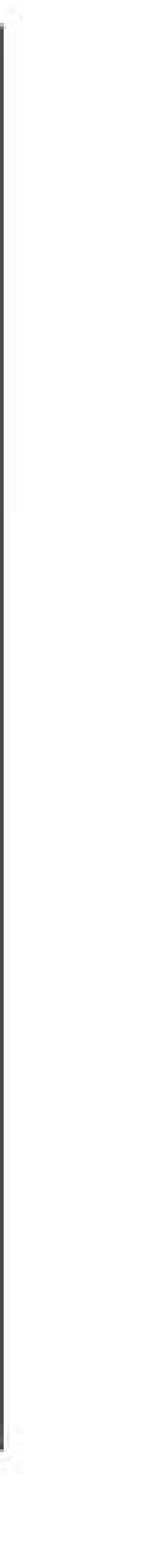
Figure 4. Stone Age and Bronze Age / Early Metal Age paddles from a) Lyngmo, Troms b) Hornneset, Nordland c) Ropelv,

a)

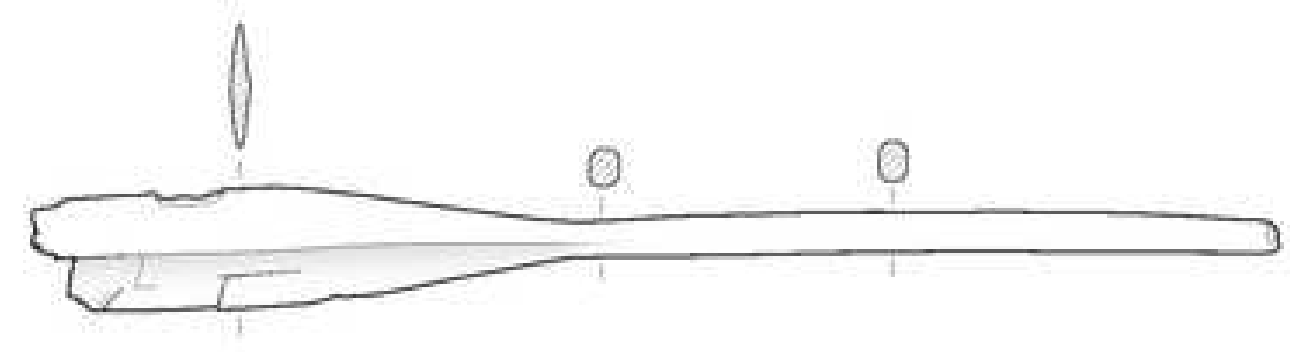

b)

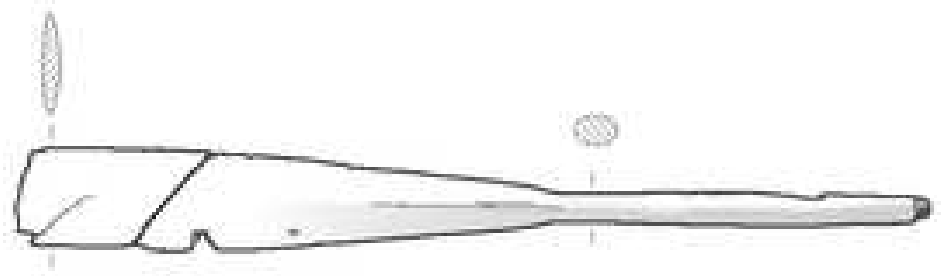

c)

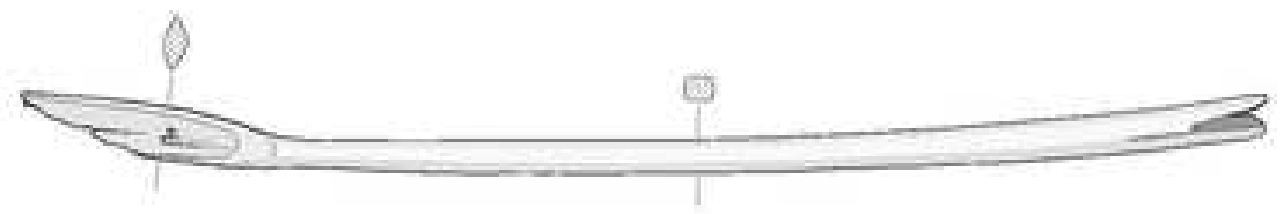

d)

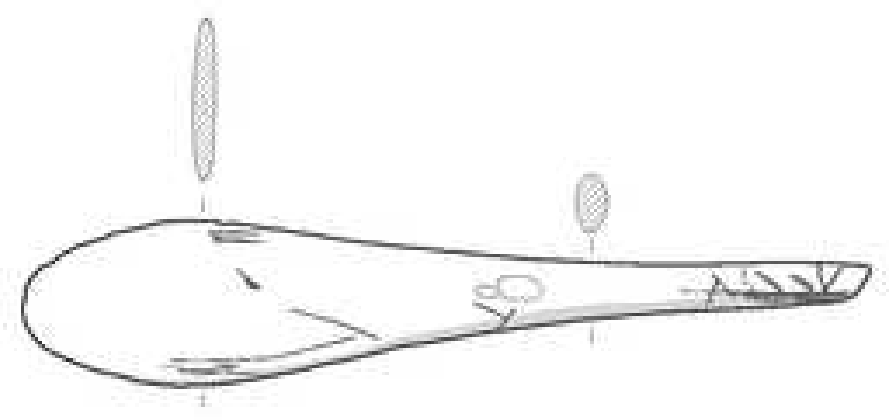

0 
Figure 5. Boat frame from Grunnfarnes, Senja Island in Troms with suggested reconstruction. Adnan Icagic, Troms $\varnothing$ University Museum.

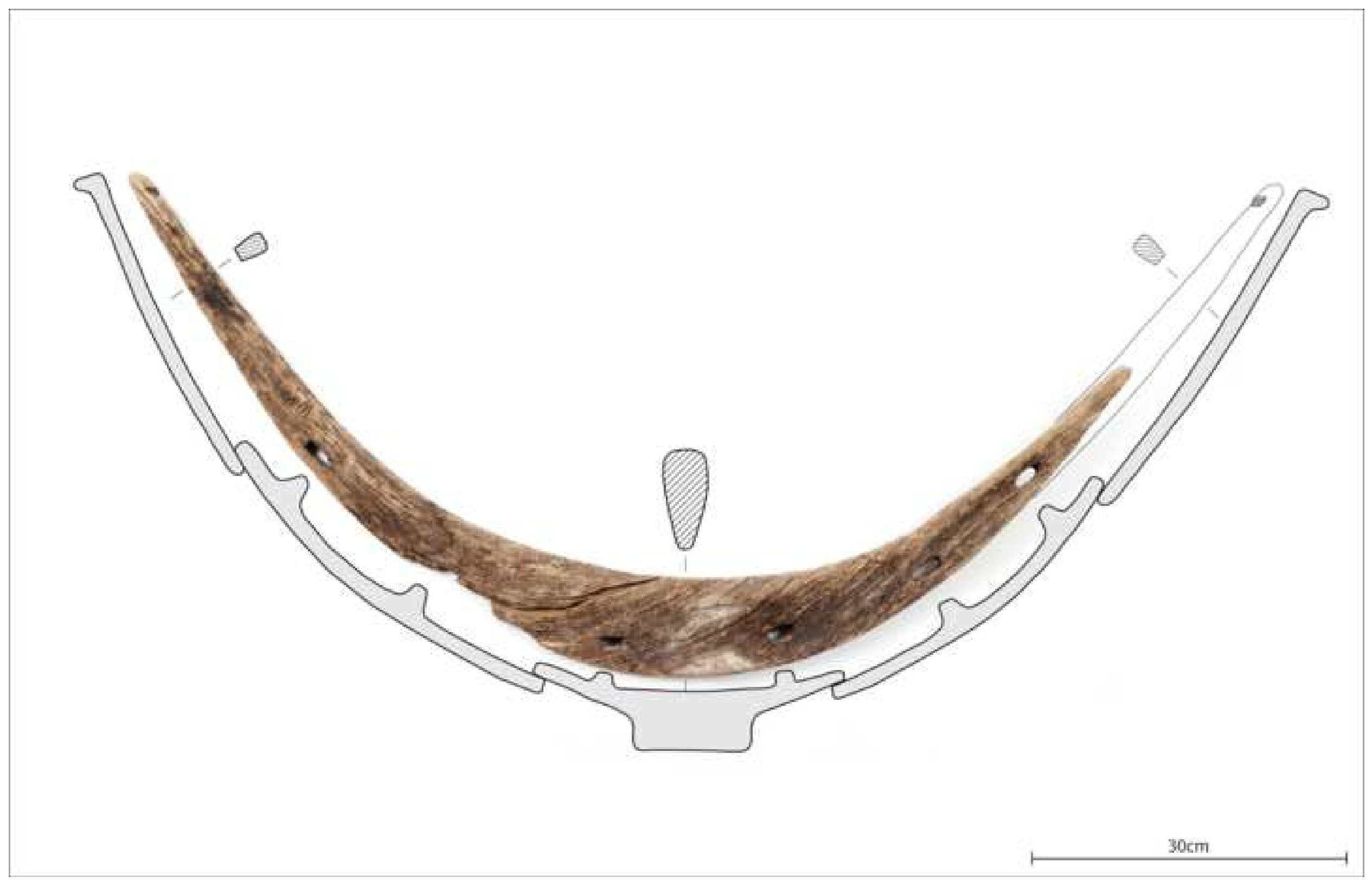


Figure 6. Boat frame fragment from the island of Børøya, Stokmarknes, Nordland with suggested reconstruction and detail inset of upper arm with inscribed linear decoration

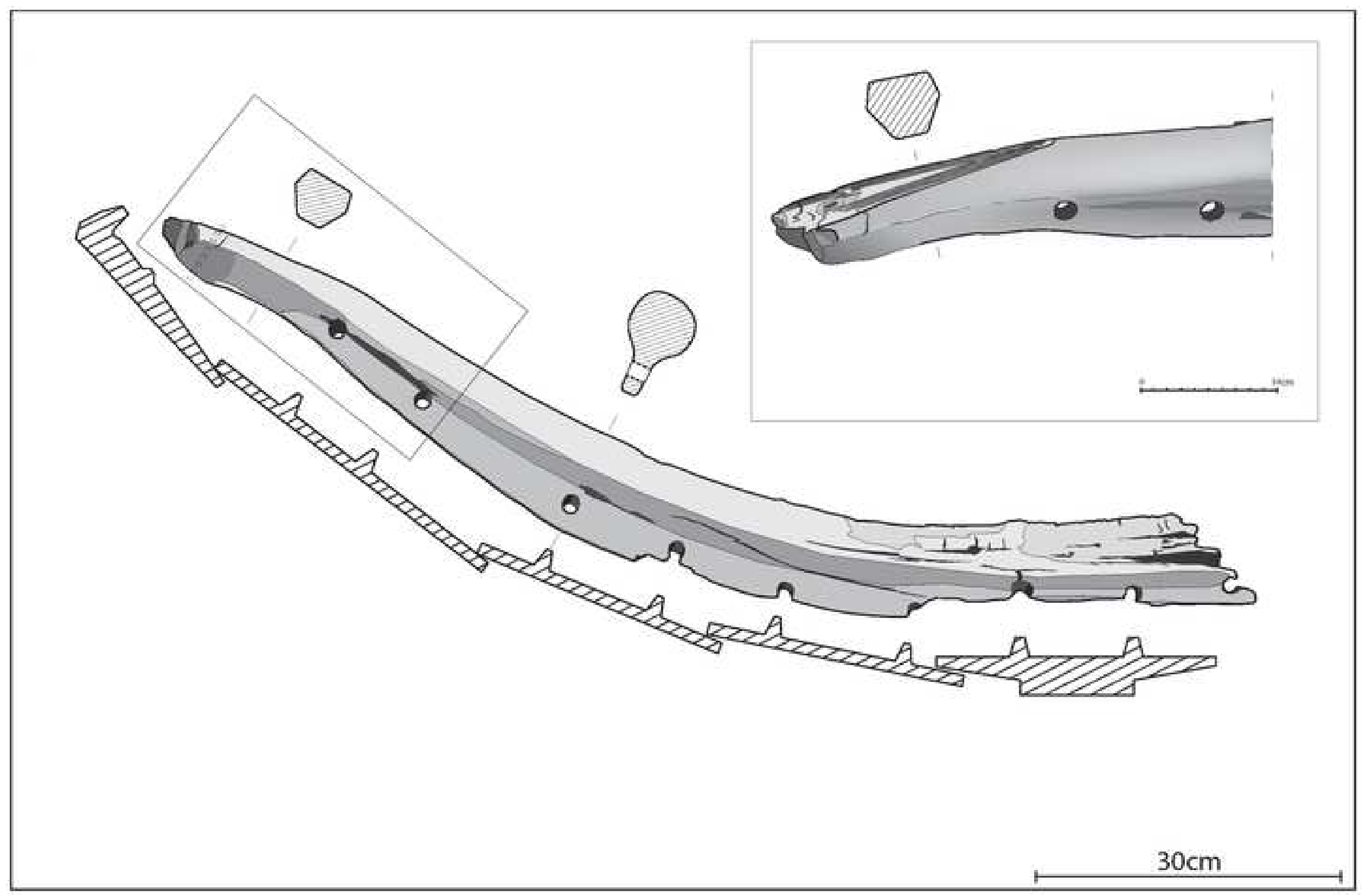


Figure 7. Pre-Roman Iron Age oars: a) unknown provenance, b) Hersøy, Troms, c)

Hofsøy, Troms. Adnan Icagic, Tromsø University Museum.

a)

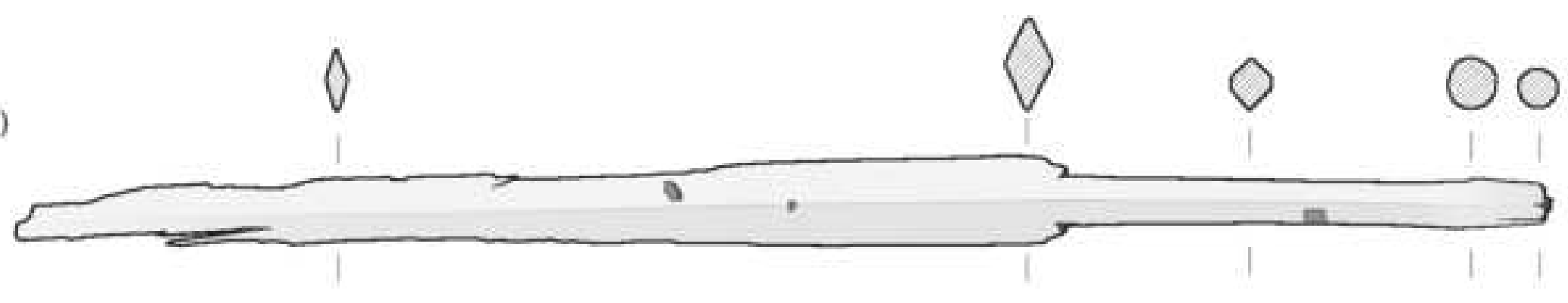

b)

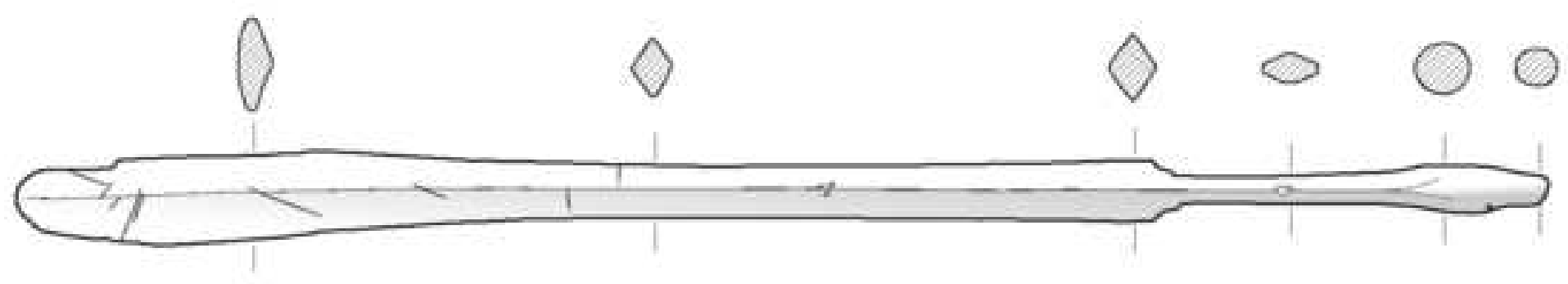

c)

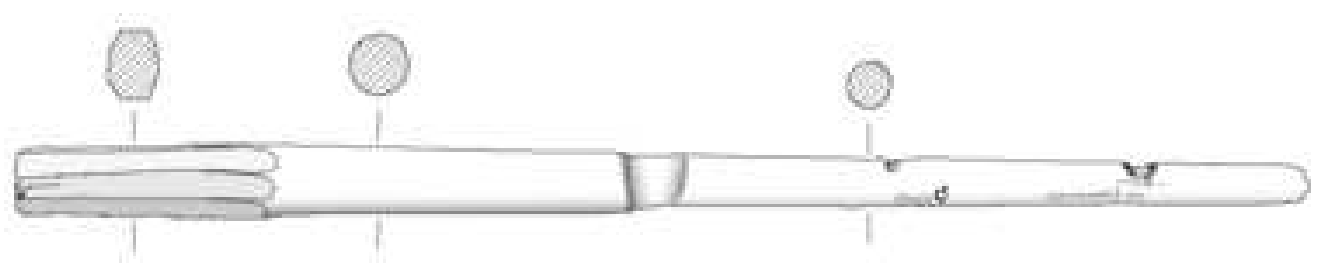


Figure 8. Detail view of Pre-Roman Iron Age oar shaft with unknown provenance.
Adnan Icagic, Troms $\varnothing$ Univerity Museum.

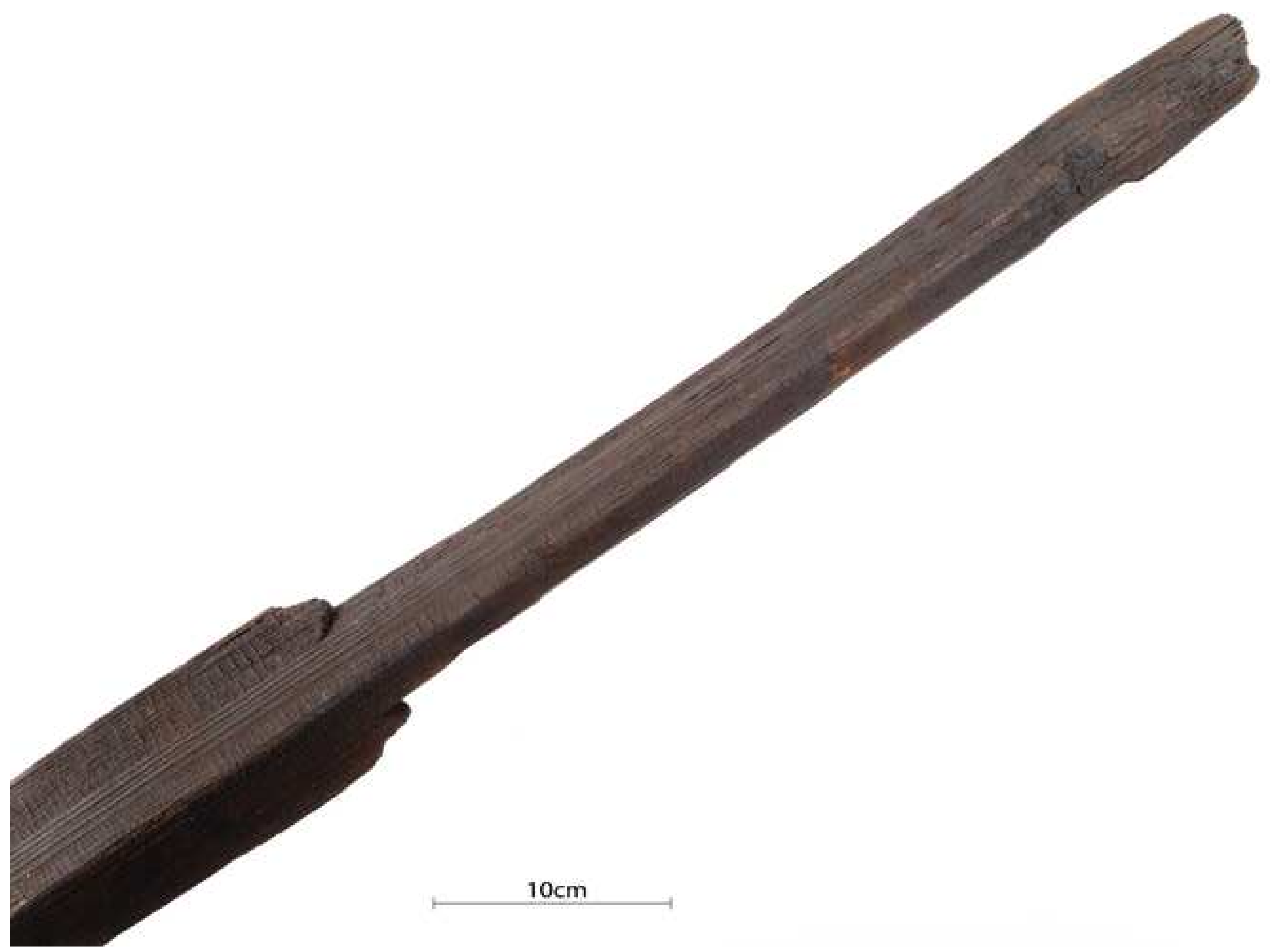


Figure 10. a) Photograph of a copy of the Hersøy oar with reconstructed shaft, b)

Photograph of the original Hersøy oar fragment, c) Line drawing and photograph of

a)

b)

c) 

Norwegian rowboat (færing). Gunnar Eldjarn, Troms $\varnothing$ University Museum.

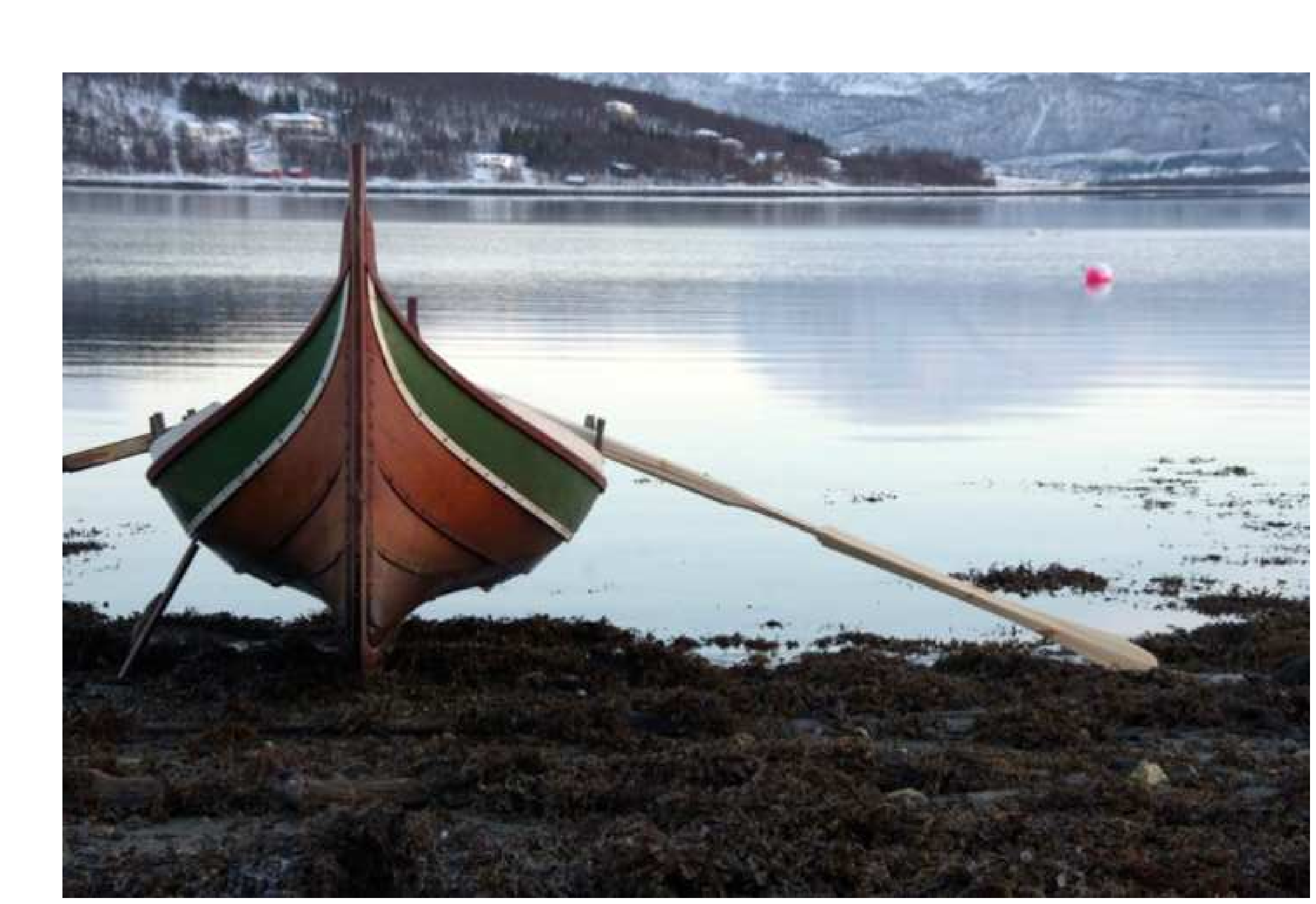

Figure 11. Photograph of Hersøy oar copy being used in a traditional norther 

Flgure 12. Photograph of a rowlock from Stonglan
Island. Adnan Icagic, Troms $\varnothing$ University Museum.

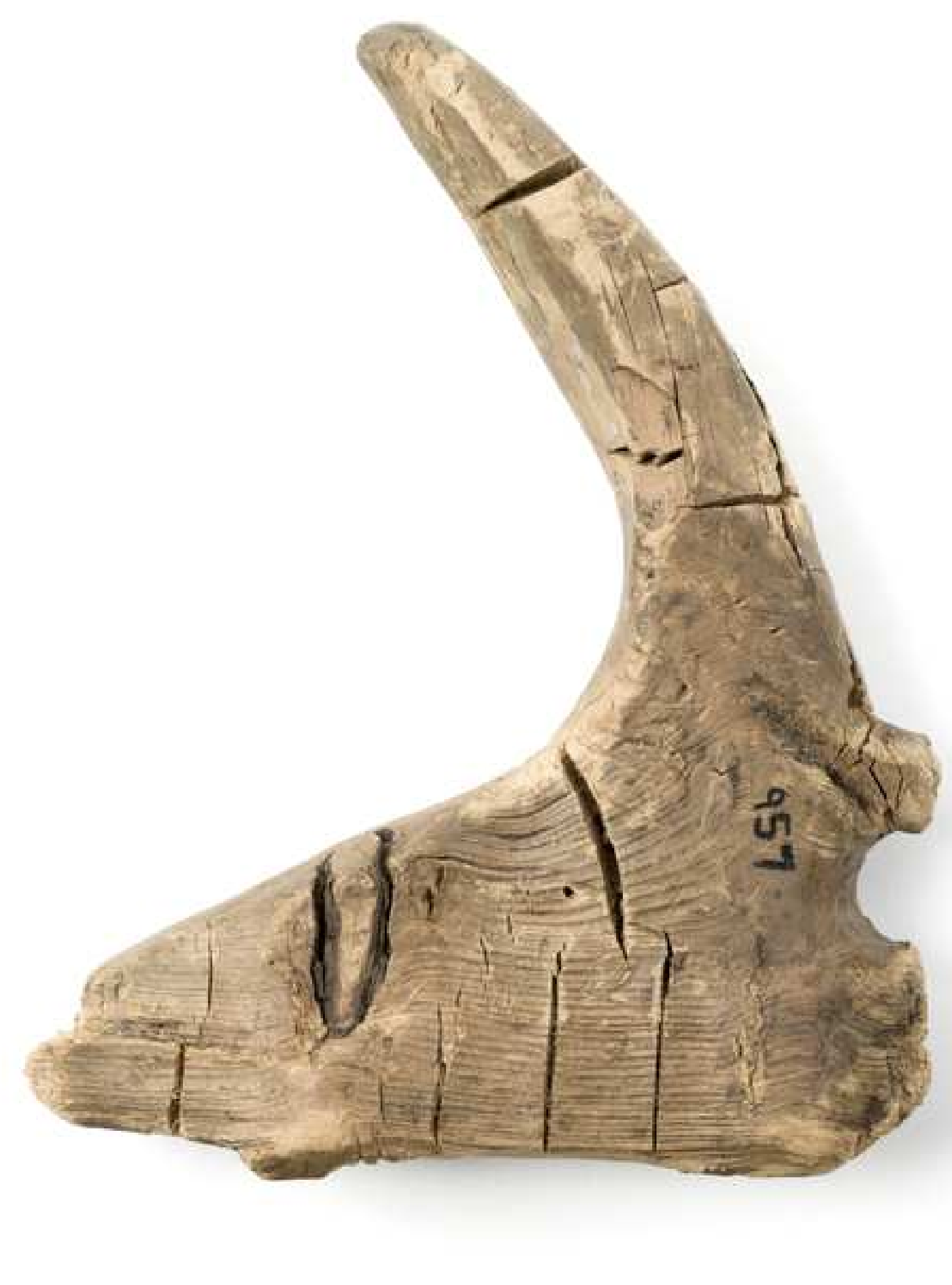

$10 \mathrm{~cm}$

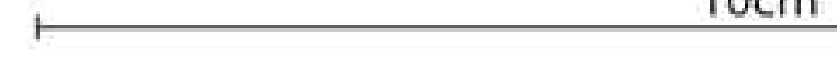

(20) 